\title{
IMPLEMENTASI AJARAN TRI KAYA PARISUDHA DALAM MEMBANGUN KARAKTER GENERASI MUDA HINDU DI ERA DIGITAL
}

\author{
Oleh: \\ Ayu Veronika Somawati, Yunitha Asri Diantary Ni Made \\ (ayuveronika@stahnmpukuturan.ac.id,yunithaasri@stahnmpukuturan.ac.id) \\ STAHN Mpu Kuturan Singaraja
}

\begin{abstract}
The development of the world into the digital era greatly affects human life. In addition to providing the positive impact, the negative impact is also unavoidable. The ease of accessing information through the internet turned out to affect the lifestyle, especially for the young Hindu generation. One of the ways to fortify themselves from the influence of negative impacts is to re-explore the Vedic teachings about character. One of them is Tri Kaya Parisudha. By knowing, believing in and implementing the Tri Kaya Parisudha, it is hoped that the young Hindu generation can be wiser in everyday life.
\end{abstract}

Keywords : Implementation, Tri Kaya Parisudha, Young Hindu Generation, Digital Era

\section{PENDAHULUAN}

Seiring dengan perkembangan ilmu pengetahuan dan teknologi yang begitu pesat, secara langsung telah mempengaruhi dimensi kehidupan manusia. Era digital seperti saat ini mengantarkan manusia kepada jaman dimana semua informasi dapat diperoleh dengan begitu mudahnya. Tidak ada lagi sekat antara budaya yang satu dengan budaya yang lain. Semua bisa diakses tanpa perlu melakukan perjalanan. Tetapi ibarat dua buah mata koin yang tidak dapat terpisahkan satu sisi dengan sisi yang lainnya, pengaruh ini tidak hanya mendatangkan sisi positif semata, sisi negatif menjadi suatu hal yang tidak dapat dielakkan. Era digital disatu sisi memberikan berbagai kemudahan dalam kehidupan manusia, dimana manusia cenderung bisa melakukan aktifitas dengan praktis, ekonomis dan cepat. Informasi mengenai keadaan di belahan dunia lain bukanlah hal yang sulit untuk ditemukan. Dengan sekali "klik" semua informasi akan didapatkan. Namun disisi lain, perlu juga disadari dampak negatif dari perkembangan IPTEK dan era digital tersebut membawa imbas yang cukup besar terhadap perkembangan dunia pendidikan di Indonesia. Berbagai macam fenomena sosial mencuat ke permukaan sebagai produk hasil dari adanya kemajuan 
pengetahuan. Banyak informasi-informasi yang justru menggiring pola pikir, pola berbicara dan tingkah laku menuju ke hal-hal yang justru tidak sesuai dengan adat dan budaya khususnya di Indonesia.

Kebebasan manusia dalam mengeksplorasi berbagai informasi secara perlahan memberikan pengaruh terhadap pola pikir, cara bertutur dan perilaku masyarakat, khususnya bagi generasi muda Hindu. Salah satu contohnya adalah dengan adanya kemajuan teknologi seperti pelayanan internet masuk desa, para generasi muda dapat secara leluasa dan dengan mudahnya mengakses berbagai informasi. Jika ditinjau dari segi positifnya, hal ini membuat masyarakat khususnya para generasi muda menjadi "melek" teknologi, membuka cakrawala mereka mengenai dunia. Tetapi ironinya, tidak sedikit generasi muda yang juga memanfaatkan fasilitas media internet untuk mencari informasi di luar batas kewajaran seperti gambar, video porno yang semestinya tidak pantas dikonsumsi oleh remaja. Akibatnya dari adanya penyalahgunaan media informasi tersebut menyebabkan terjadinya berbagai penyimpangan pola pikir seperti pola pikir yang tidak sesuai dengan umurnya, gaya berpacaran layaknya orang dewasa, pola berbicara yang tidak sesuai dengan norma, hingga terjadi berbagai penyimpangan perilaku, seperti aksi bullying, perilaku asusila, pergaulan bebas, pemerkosaan serta kehamilan di bawah umur. Pergaulan bebas dan terjerumus dalam pengaruh minuman keras terlebih sebagai pemakai dan pecandu narkoba merupakan ancaman serius yang secara perlahan tapi pasti mengancam eksistensi generasi muda sebagai generasi penerus bangsa.

Realita tersebut di atas merupakan suatu indikasi adanya pergeseran kebudayaan, sebagai bentuk memudarnya nilai budaya bangsa dan identitas diri manusia Indonesia. Menyikapi adanya degradasi moral tersebut, perlu adanya suatu terobosan untuk mencari solusi guna meminimalisir berbagai permasalahan tersebut, salah satunya adalah dengan pendekatan, memberikan pengarahan serta sosialisasi secara dini yang dimulai dari lingkungan keluarga, sekolah dan masyarakat. Bentuk sosialisasi di lingkungan keluarga dapat dilakukan dengan cara pendekatan antara orang tua dengan anak maupun antar saudara. Bentuk sosialisasi di lingkungan sekolah dapat dilakukan dengan cara memberikan pemahaman pada setiap mata pelajaran yang di ajarkan di sekolah yang di dalamnya diselipkan berbagai nilai karakter yang mengandung muatan etika dan disiplin. Sedangkan di lingkungan 
masyarakat sendiri, dapat dilakukan melalui kegiatan-kegiatan kepemudaan, penyuluhan dan pembinaan, dan lain sebagainya. Selain dengan cara tersebut, cara lain untuk memperkuat para generasi muda khususnya generasi muda Hindu dalam menghadapi era digital seperti saat ini adalah dengan penanaman dan penguatan nilainilai karakter yang terdapat di dalam ajaran agama Hindu.

Ajaran Hindu senantiasa menuntun umatnya untuk menjaga keselarasan melalui perspektif Tri Hita Karana, yakni menjaga keselarasan dengan Sang Pencipta atau parhyangan, menjaga keselarasan dengan sesama manusia atau pawongan, serta menjaga keselarasan dengan lingkungan atau palemahan. Ajaran mengenai keselarasan ini diaktualisasikan salah satunya adalah melalui ajaran-ajaran etika atau susila. Adanya ajaran-ajaran etika atau susila tersebut memberikan pemahaman kepada umat Hindu, khususnya kepada generasi muda Hindu secara mendalam mengenai apa yang baik dan yang kurang baik, yang benar dan yang salah, sehingga melahirkan tingkah laku yang mencerminkan hakikat beragama yaitu percaya dan bhakti kepada Ida Sang Hyang Widhi Wasa dan hubungan yang baik antar sesama manusia serta dengan lingkungan dimana manusia itu tinggal.

Etika adalah nilai-nilai dan norma-norma moral yang menjadi pegangan bagi seseorang atau suatu kelompok dalam mengatur tingkah lakunya (Bertens, 2013). Dalam konteks menghadapi era digital yang penuh dengan segala macam bentuk persaingan ini, manusia sebagai makhluk sosial perlu membina hubungan yang serasi dan harmonis dengan orang lain atas dasar saling menghormati dan menghargai. Dalam kehidupan bersama orang harus mengatur dirinya bertingkah laku. Tidak seorangpun boleh berbuat sekehendak hatinya. Setiap orang harus menyesuaikan diri dengan lingkungannya, tunduk dengan aturan bertingkah laku yang berlaku. Dengan demikian maka setiap orang hanya bebas berbuat dalam ikatan aturan tingkah laku yang baik.

Agama ialah dasar etika atau susila yang kokoh dan kekal, ibarat landasan bangunan dimana suatu bangunan harus didirikan. Jika landasan itu tidak kuat, maka bangunan akan mudah roboh. Jika landasan atau pondasi dari bangunan tersebut kuat, maka bangunan itu akan berdiri tegak dan kokoh menghadapi hujan badai yang bisa saja terjadi. Demikian halnya juga dengan etika atau susila; bila tidak dibangun atas dasar agama sebagai landasan yang kokoh dan kekal, maka ajaran tersebut tidak akan 
mendalam dan tidak meresap dalam diri pribadi manusia. Demikian pula sebaliknya, susila merupakan wujud pengamalan dari ajaran agama dalam perilaku yang baik dan mulia.

Etika Hindu atau susila tidaklah mewajibkan umatnya untuk hanya terpaku pada ritual-ritual keagamaan dan mengabaikan kegiatan-kegiatan yang berhubungan dengan keduniawian serta pemenuhan kebutuhan dan keinginan manusia. Etika Hindu atau susila ini lebih menekankan pada bagaimana anggota masyarakat bisa menyelaraskan segala tindakan dan perilakunya sebagai makhluk individu dan makhluk sosial, serta menyeimbangkan antara kebutuhan dan keinginannya dengan kegiatan yang berhubungan dengan intelektual serta spiritual. (Pandit, 2003) Etika Hindu tidak menyarankan menekan keinginan dan emosi, tetapi memuaskan keinginan dan emosi itu dalam tindakan yang terkendali sehingga energi tidak terbuang untuk pengejaran hal-hal duniawi. Energi yang mencukupi harus tetap ada bagi evolusi intelektual dan spiritual. Beberapa kebaikan yang meningkatkan evolusi seorang individu adalah kebenaran, tidak melakukan kekerasan, cinta, keadilan, cinta kasih, keberanian, kebijaksanaan, toleransi, kesenangan, pengampunan, kemurnian pikiran, kata-kata dan perbuatan, serta pengendalian diri.

Agama Hindu dengan segala keuniversalannya yang bersumber dari kitab suci Veda memiliki begitu banyak ajaran mengenai etika Hindu atau susila, salah satunya adalah ajaran Tri Kaya Parisudha. Ajaran Tri Kaya Parisudha inilah yang jika diketahui, dipahami dan diimplementasikan di dalam kehidupan umat Hindu khususnya generasi muda Hindu, maka generasi muda Hindu akan memiliki pondasi yang kuat untuk dapat menyikapi permasalahan moral yang banyak terjadi belakangan ini sebagai imbas dari perkembangan era digital yang tidak bisa dihindari. Tujuan dari tulisan ini adalah untuk mengkaji nilai-nilai etika yang terkandung di dalam ajaran Tri Kaya Parisudha sehingga dapat diketahui dan diimplementasikan dalam kehidupan sehari-hari guna membangun karakter generasi muda Hindu.

\section{TRI KAYA PARISUDHA, JAWABAN BAGI GENERASI MUDA HINDU DI ERA DIGITAL}

Kelahiran sebagai manusia merupakan suatu anugerah yang utama, karena hanya yang lahir sebagai manusia yang dilengkapi dengan Tri Premana, yakni kekuatan (bayu), kemampuan untuk bersuara atau berbicara (sabda), serta 
kemampuan untuk berpikir (idep). Tumbuhan hanya dibekali dengan bayu. Binatang hanya dibekali bayu dan sabda. Tetapi manusia selain dibekali bayu dan sabda, dibekali pula dengan idep. Idep inilah yang membuat manusia menjadi istimewa jika dibandingkan dengan makhluk hidup yang lainnya. Seperti yang termuat dalam sloka Sarasamuccaya 2 berikut:

Mānusah sarvabhūteșu vartatte vai șubhāśubhe, Terjemahan: Aśubheșu samaviștam śubhesvevāvakārayet

Diantara semua makhluk hidup, hanya yang dilahirkan menjadi manusia sajalah, yang dapat melaksanakan perbuatan baik ataupun buruk; leburlah ke dalam perbuatan baik, segala perbuatan yang buruk itu; demikianlah gunanya (pahalanya) menjadi manusia (Kadjeng, 1997).

Kesempatan "langka" seperti ini tentu tidak boleh disia-siakan begitu saja. Berbekal kesempatan menjelma sebagai manusia dengan segala kelebihannya, manusia juga mendapat kesempatan untuk memperbaiki kualitas diri dengan selalu memperhatikan pikiran, perasaan dan perilaku diri, serta dampaknya terhadap orang lain (self-awareness). Oleh karena itu, dengan melaksanakan perbuatan yang berdasarkan pada kebaikan atau dharma, maka hidup akan jauh lebih berguna dan bermakna bagi orang lain. Secara umun ajaran yang berkaitan dengan nilai-nilai kepemimpinan (leadership) yang adiluhur. Inilah yang patut diamalkan oleh generasi muda penerus bangsa (Hartaka, 2018).

Melakukan perbuatan diluar tuntunan dharma, tentu akan mengarahkan diri kepada kesedihan dan perasaan tidak berguna. Serta pada akhirnya, hasil-hasil dari perbuatan inilah yang akan mengantarkan manusia hingga ke kehidupan yang akan datang. Seperti yang termuat di dalam kitab Slokāntara 13 sebagai berikut:

Terjemahan:

Artha gṛhe nivartante śmaśāne mitrawāndhawāh

sukrtaim duskrtaim caiwa chāyāwadanugacchati

Kekayaan itu hanya tertinggal di rumah setelah kita meninggal dunia, kawankawan dan sanak keluarga hanya mengikuti sampai di kuburan. Hanya karmalah, yaitu perbuatan baik atau buruk itu, yang mengikuti jiwa kita sebagai bayangannya (Sudharta, 2003).

Kehidupan manusia jaman sekarang yang sudah memasuki era digital, dimana semua manusia mulai sibuk dengan kepentingan masing-masing tentu saja secara 
langsung maupun tidak langsung berdampak kepada self-awareness tersebut. Di era yang serba cepat dan instan ini, orang tidak lagi memperhatikan pikiran, perasaan dan perilaku diri, serta dampaknya terhadap orang lain. Banyak orang yang justru terjebak dalam penerimaan kemunculan era digital yang menjadikan manusia menjadi tidak manusiawi seperti memudar atau bahkan menghilangnya nilai-nilai etika, moral dan budaya. Contoh sederhananya saja di lingkungan akademik kampus, jaman sekarang tidak jarang mahasiswa lebih memilih untuk sibuk memperhatikan gadgetnya dan berselancar di dunia maya seperti berselancar facebook, update status di instagram, twitter dan lain-lainnya dibandingkan harus memperhatikan dosennya yang sedang mengajar. Hal ini menunjukkan bahwa self-awareness tidak lagi menjadi penting dan nilai-nilai etika tidak lagi menjadi prioritas. Untuk menghadapi tantangan seperti ini, sesungguhnya sangatlah dibutuhkan kesiapan dari setiap orang untuk dapat menerima perubahan-perubahan sebagai imbas dari era digital tanpa meninggalkan nilai-nilai etika yang telah ada di dalam masyarakat.

Ajaran agama Hindu yang begitu universal dan fleksibel memiliki berbagai macam ajaran guna membimbing umatnya ke arah yang lebih baik, termasuk untuk menghadapi tantangan dalam memasuki era digital ini. Melalui Tiga Kerangka Dasar Agama Hindu khususnya pada bagian susila atau etika, umat Hindu khususnya para generasi muda Hindu diharapkan mengetahui, menghayati serta mengimplementasikan ajaran-ajaran etika tersebut guna membentengi diri dari pengaruh negatif era digital yang tidak hanya memberikan dampak positif dalam perkembangannya, tetapi bisa saja pengaruhnya justru bertentangan dengan nilai-nilai susila yang terdapat di dalam ajaran Agama Hindu. Selalu meningkatkan kualitas diri dan penguatan karakter menjadi suatu tanggung jawab bagi diri sendiri khususnya bagi diri generasi muda Hindu guna menyongsong masa depan agama Hindu yang lebih baik dan untuk membentengi diri dari pengaruh negatif dari era digital yang semakin lama semakin mempegaruhi setiap sisi kehidupan manusia.

Salah satu ajaran mengenai etika yang terdapat di dalam konsep agama Hindu adalah Tri Kaya Parisudha. Tri artinya tiga. Kaya artinya perbuatan, kegiatan atau wujud. Parisudha yang berarti baik, bersih, suci atau disucikan. Tri Kaya Parisudha adalah tiga dasar perilaku yang harus disucikan, yaitu pikiran, perkataan dan perbuatan. Bagian dari Tri Kaya Parisudha ini adalah (1) Manacika Parisudha 
yang artinya berpikir yang suci atau yang benar, (2) Wacika Parisudha yang artinya berkata yang benar, dan (3) Kayika Parisudha yang artinya berbuat yang benar. Maksud berpikir, berkata, dan berbuat yang benar ini dianggap benar jika selalu mengacu pada pandangan dharma (kebenaran). (Suhardana, 2007) kata disucikan dimaksudkan bahwa pikiran, perkataan dan perbuatan manusia itu tidak boleh dinodai dengan jalan yang tidak baik. Pikiran, perkataan dan perbuatan baik itu harus selalu dijadikan pedoman oleh umat Hindu dalam mengarungi kehidupan ini, sehingga terpeliharalah adanya kerukunan, ketenteraman dan kedamaian dalam masyarakat.

\section{MANACIKA PARISUDHA.}

Acapkali dikatakan bahwa faktor yang membedakan makhluk manusia dari binatang yang lain adalah kemampuan untuk menalar. Banyak binatang yang lain kurang lebih sampai taraf tertentu, sadar akan dunia fisis dan memberikan respon terhadapnya, tetapi manusia mengklaim lebih dari sekedar kesadaran. Manusia juga memiliki sejenis pemahaman (understanding) tentang dunia, dan tentang tempat kita di dalamnya (Davies, 2012). Pernyataan tersebut menunjukkan bahwa pada makhluk lain seperti binatang, kemampuannya hanya sampai pada tahap naluri atau insting. Ketika merasa lapar, binatang akan pergi mencari makanan. Ketika mengantuk, binatang akan tidur begitu saja. Binatang hanya mengikuti pola reaksi terhadap rangsangan tertentu begitu saja. Berbeda dengan manusia yang selain memiliki naluri, juga memiliki nalar yang membuat manusia dikategorikan menjadi makhluk yang istimewa. Dengan kemampuan menalar, manusia mampu berpikir logis serta membedakan yang baik dan yang buruk.

Sebagai agama yang begitu universal dan mencakup segala aspek kehidupan manusia, agama Hindu juga memiliki dan menawarkan konsep mengenai keistimewaan manusia tersebut. Salah satunya adalah Manacika Parisudha yang merupakan salah satu bagian dari ajaran Tri Kaya Parisudha. Manacika Parisudha artinya adalah berpikir yang suci atau yang benar. Pikiran menjadi konsep pertama yang dibahas karena posisinya sebagai "raja indriya", yang mengendalikan seluruh indriya di dalam diri manusia. Selain itu, pikiranlah yang akan menuntun manusia untuk berkata dan bertindak. Hal ini tersirat dengan jelas pada kutipan sloka Sarasamuccaya 80 berikut : 
Mano hi mūlam sarvesāmindrayānam pravartate, șubhāśubhasvavasthāsu kāryam tat suvyavasthitam Terjemahan :

Sebab yang disebut pikiran itu, adalah sumbernya nafsu, ialah yang menggerakkan perbuatan yang baik ataupun yang buruk; oleh karena itu, pikiranlah yang segera patut diusahakan pengekangannya / pengendaliannya (Kadjeng, 1997).

Kehidupan setiap manusia dihadapkan dengan berbagai masalah dalam kesempatan hidupnya. Apalagi jika dilihat dari sudut pandang generasi muda Hindu khususnya yang tentu saja pada usia yang relatif muda dan masih dalam proses pencarian jati diri masalah akan terlihat lebih kompleks. Masalah-masalah itu akan bisa dihadapi, bila hati atau pikiran dapat dikendalikan dari hawa nafsu yang mempengaruhinya. (Śivānanda, 2005) ketika manusia berpikir, maka demikianlah ia jadinya "Manusia diciptakan oleh pikiran; apa yang dipikirkannya maka demikianlah ia jadinya" berpikirlah bahwa anda kuat maka anda akan menjadi kuat. Berpikirah bahwa anda orang yang bodoh, maka anda akan menjadi orang bodoh.

Kekuatan pikiran yang begitu dahsyat jika diarahkan untuk memotivasi diri tentu saja akan memberikan efek yang luar biasa. Sehingga tidak mengherankan, jika kajian-kajian mengenai cara kerja pikiran mulai digencarkan dengan tujuan untuk mengarahkan diri manusia kepada kehidupan yang jauh lebih baik. Gulo (2019) menguraikan bahwa kegagalan banyak orang dalam kehidupannya karena pikirannya sendiri yang memang lemah, lunglai dan putus asa. Pikiranlah yang memberitahukan kepada seluruh tubuh apakah dia berhasil atau tidak. Kalau pikirannya mengatakan "kamu berhasil, maka harusnya dia berhasil". Sebaliknya, kalau pikirannya mengatakan "kamu akan gagal, maka percayalah kegagalan itu sudah terjadi sebelum mencoba". Hal tersebut juga dijelaskan di dalam susastra Hindu, yakni di dalam Sarasamuccaya 79 yang berbunyi :

Manasā nicayam krtva tato vaca vidhiyate, kriyate

Karmanā paṣcāt pradhānam vai manastatah

Terjemahan :

Maka kesimpulannya, pikiranlah yang merupakan unsur yang menentukan; jika penentuan perasaan hati telah terjadi, maka mulailah orang berkata, atau melakukan perbuatan; oleh karena itu pikiranlah yang menjadi pokok sumbernya (Kadjeng, 1997). 
Kekuatan pikiran sangatlah luar biasa dan tidak terbatas oleh ruang dan waktu. Mungkin tidak disadari oleh manusia jika kekuatan pikirannya menghasilkan energi yang secara langsung dapat mempengaruhi orang lain bahkan alam semesta. (Yudiantara, 2016) karena sebagaimana juga alam semesta, pikiran andapun adalah medan energi yang memiliki frekuensi dan vibrasi tertentu, wajar jika hanya dengan pikiran anda bisa mempengaruhi realitas di alam semesta ini. Wajar jika hanya dengan visualisasi dan afirmasi saja, anda bisa mempengaruhi orang lain, sebab orang lainpun adalah medan energi yang bisa digetarkan oleh energi pikiran anda, oleh apa yang anda ungkapkan dalam pikiran anda (sabda; afirmasi) dan apa yang anda bayangkan di dalam pikiran anda (bhavana; visualisasi).

Menyadari kehebatan dari pikiran itu sendiri, manusia harus menanamkan pemikiran-pemikiran yang baik guna selalu memberikan energi positif bagi orang lain dan juga alam semesta dimana manusia itu hidup. Ajaran Manacika Parisudha menuntun manusia untuk berpikir yang baik, berusaha menolong dirinya dengan mengendalikan pikirannya sebelum akan berkata-kata dan berbuat. Mereka yang kuat mengendalikan pikirannya sehingga tidak mengumbar hawa nafsunya akan lebih mudah mencapai cita-citanya. Mereka tidak banyak digoda atau diperbudak oleh hawa nafsunya. Demikian sebaliknya mereka yang kurang mampu mengendalikan hawa nafsunya sulit mencapai cita-citanya, karena pikirannya terbelenggu hingga lupa apa yang dilakukan. Langkah-langkah yang perlu dilakukan untuk mengendalikan pikiran adalah:

- Biasakan berpikir dan bersikap welas asih terhadap sesama makhluk dan memupuknya secara terus menerus,

- Berlatih untuk mengendalikan diri, agar rasa iri dan dengki tidak melekat dalam hati,

- Selalu berpikir positif, mengendalikan keinginan buruk yang timbul karena pengaruh dari panca indriya,

- Sibukkan diri dengan bekerja, sehingga tidak ada kesempatan untuk melamun atau memikirkan yang bukan-bukan,

- Tanamkan terus pikiran dan sikap pengendalian diri yang baik dan benar, sehingga kita mudah memberi maaf kepada orang lain, 
- Biasakan berpikir, berkata dan berbuat yang baik sehingga dapat menjadi manusia yang berbudi pekerti luhur (Suratmini, 2012).

Contoh cerita yang dapat diambil mengenai kehebatan seseorang yang mampu mengendalikan pikirannya adalah dari cerita Arjuna Wiwaha, dimana Arjuna mendapat anugerah dari Bhatara Siwa setelah berhasil melaksanakan tapanya karena pikirannya terkendali kuat, melawan berbagai macam godaan nafsu, rasa marah atau krodha yang sering dapat dirasakan oleh setiap orang. Berpangkal pada pikiran dan hal itu patut dikendalikan agar tidak sampai kehilangan rasa keseimbangan dalam diri. Apabila seseorang tidak kuat mengendalikan pikiran dapat menimbulkan rasa sakit, bingung, marah, benci, stress, gila, tidak ingin makan dan minum, tidur, akibat pikirannya terganggu.

Umat Hindu khususnya generasi muda melalui pedoman hidup ini diharapkan mampu menjaga kesucian pikiran yakni dengan ajaran dharma itu sendiri, sebab ada pepatah lama mengatakan "dari telaga yang jernih mengalirlah air yang jernih pula", maksudnya adalah jika pikiran seseorang suci atau bijaksana maka perkataan dan perbuatan yang akan dilakukan pasti akan sejalan pula.

\section{WACIKA PARISUDHA.}

Seiring perkembangan dunia yang begitu pesat sebagai imbas dari globalisasi dan persaingan manusia dalam menyambut era revolusi industri 4.0 , berita dan informasi juga semakin cepat bisa diakses oleh setiap orang kapanpun dan dimanapun. Untuk menghasilkan sebuah berita dan informasi, seseorang tidak perlu lagi harus bersusah payah mengajukan idenya ke kantor berita dan harus menunggu konfirmasi berlama-lama. Jaman sekarang, hanya dengan berbekal telepon pintar dan koneksi internet, semua orang bisa dengan mudahnya berbagi macam hal, mulai dari yang bersifat darurat seperti bencana alam atau kecelakaan, sampai kepada hal-hal yang bersifat hiburan semata. Hanya saja, salah satu kelemahan dari cepatnya berita dan informasi yang dapat diterima adalah adanya berita-berita hoax. Informasiinformasi yang muncul ke permukaan dan menjadi trending didominasi oleh beritaberita yang tingkat keakuratannya perlu ditinjau kembali dan disampaikan oleh orang dengan kredibilitas yang patut dipertanyakan. Hal ini tentu saja perlu dikaji bersama untuk kepentingan bersama juga. 
Sebagai makhluk yang telah dibekali dengan daya nalar sebagai pembedanya dengan makhluk lain, manusia seharusnya jauh lebih bijak lagi dalam membagikan informasi kepada orang lain. Perkataan dan ucapan sebagai salah satu media untuk membagikan informasi kepada orang lain tentu harus sangat diperhatikan agar tidak memberikan kesesatan informasi. Selain itu, peribahasa "mulutmu harimaumu"pun harus dimaknai secara mendalam dan dilaksanakan agar apa yang disampaikan tidak menjadi bumerang bagi orang yang mengucapkannya.

Perkatan sangat perlu diperhatikan dan diteliti sebelum dikeluarkan karena perkataan merupakan alat yang penting bagi manusia, guna menyampaikan segala isi hati dan maksud seseorang. Melalui kata-kata seseorang dapat memperoleh suatu pengetahuan, mendapatkan suatu hiburan, serta nasehat-nasehat yang sangat berguna baik bagi seseorang maupun orang lain. Tetapi melalui kata-kata pula, seseorang dapat membuat susah orang lain dan menimbulkan kebencian. Termuat di dalam kitab Sarasamuccaya 118 sebagai berikut :

samyagalpaì ca vaktavyamaviksiptena cetasā

vākprabandho hi saìrāgādvirāgādvā bhavedasan Terjemahan :

Yang patut dikatakan itu hendaklah sesuatu yang membawa kebaikan, hal itu janganlah digembar-gemborkan; berkeinginan disebut pandai bicara; sebab kata-kata itu jika berkepanjangan, ada yang menyebabkan senang ada yang menimbulkan kebencian; tak baik hal serupa itu (Kadjeng, 1997).

Agama Hindu melalui ajarannya menuntun umat, khususnya generasi mudanya untuk selalu menjaga perkataan. Salah satunya adalah ajaran Wacika Parisudha sebagai bagian dari Tri Kaya Parisudha. Wacika Parisudha artinya berkata yang benar atau yang disucikan. Sebagai umat manusia yang sudah dibekali akal pikiran harus selalu berusaha menjaga perkataan. Sebab jika perkataan itu kalau tidak terkontrol pasti akan dapat menimbulkan bencana, baik bagi diri sendiri maupun orang lain. Berkenaan dengan itu didalam kitab Nitisastra sargah V.3 menyebutkan sebagai berikut:

Wasita nimittanta manemu laksmi, Wasita nimittanta pati kapangguh, Wasita nimittanta manemu duhka, Wasita nimittanta manemu mitra. 
Terjemahan:

Dengan perkataan engkau akan mendapatkan bahagia,

Dengan perkataan engkau akan menemui kematian,

Dengan perkataan engkau mendapat kesengsaraan,

Dengan perkataan engkau akan mendapatkan teman.

Makna yang tersirat pada sloka diatas "perkataan yang keluar dari mulut seseorang itu bagaikan paku yang menancap pada sepotong kayu. Bisa saja paku yang telah menancap tersebut ditarik, tetapi bekas tancapan tersebut tidak akan pernah hilang dan selalu berbekas. Bisa saja seseorang telah meminta maaf atas perkataan yang baik secara sengaja maupun tidak sengaja menyinggung perasaan orang lain, tetapi bekas dari ucapan tersebut tidak akan pernah bisa terhapuskan begitu saja dari ingatan orang yang terlanjur tersakiti.

Perkataan yang manis dengan maksud baik tentu akan sangat menyenangkan jika didengar oleh setiap orang. Perkataan itu patut timbul dari hati yang tulus, lemah lembut penyamapaiannya dan menyenangkan hati pendengarnya. Untuk dapat berkata yang baik patut dipikirkan terlebih dahulu. Terlanjurnya berkata-kata akan sulit ditarik kembali. Kata-kata merupakan saran komunikasi yang paling cepat diterima di dalam pergaulan, perhubungan, pendidikan, penyuluhan, penerangan dan lain sebagainya. Perkataan yang baik diusahakan untuk angawe suka wong len, yaitu mengusahakan kesenangan untuk orang lain, karena orang lainlah yang akan mendengar dan merasakannya. Karena meskipun maksud yang ingin disampaikan adalah baik, tetapi jika disampaikan dengan cara yang tidak sopan belum tentu akan menghasilkan reaksi yang baik dari orang yang mendengarkannya. Seperti yang termuat di dalam kitab Sarasamuccaya 119 sebagai berikut :

Abhyāvahati kalyāṇam vividham vāk subhāṣitā, Terjemahan :

Saiva durbhāṣita pumsāmanarthāyopapadyate

Karena perkataan itu jika maksudnya baik, dan secara baik pula diucapkannya, hanyalah kesenangan yang ditimbulkan olehnya; meski maksudnya baik, jika tidak secara baik diucapkannya, bahkan kepada yang mengucapkannya pun menimbulkan hati duka (Kadjeng, 1997).

Menjaga perkataan yang akan disampaikan kepada orang lain merupakan suatu keniscayaan yang patut dijaga demi kebahagiaan manusia bersama. Apalagi dijaman seperti sekarang ini, dimana semua orang berlomba-lomba menunjukkan eksistensi 
diri untuk kepentingan diri pribadi, setidaknya tetap menjaga perasaan orang lain tidak boleh terlupakan. Melalui ajaran Wacika Parisudha ini, umat Hindu khususnya generasi muda Hindu diarahkan untuk selalu menjaga kesucian perkataannya. Bahkan termuat dalam kitab Sarasamuccaya 75, kata-kata seperti apa saja yang tidak boleh diniatkan untuk diucapkan, apalagi jika sampai keluar dari mulut seseorang sebagai berikut :

Asatpralāpam pārusyam paicunyamanrtam tathā, Vatvāri vācā rājendra na jalpennānucintayet

Terjemahan :

Inilah yang tidak patut timbul dari kata-kata, empat banyaknya, yakni perkataan jahat, perkataan kasar menghardik, perkataan memfitnah, perkataan bohong (tak dapat dipercaya); itulah keempatnya harus disingkirkan dari perkataan, jangan diucapkan, jangan dipikir-pikir akan diucapkan (Kadjeng, 1997).

Selain itu, terdapat empat macam perbuatan melalui perkataan yang patut dikendalikan, yaitu : (1) tidak suka mencaci maki, (2) tidak berkata-kata kasar pada siapapun, (3) tidak menjelek-jelekkan, apalagi memfitnah makhluk lain, dan (4) tidak ingkar janji atau berkata bohong (Kusuma, 2017).

\section{KAYIKA PARISUDHA.}

Sebagai makhluk sosial, manusia tentu saja tidak dapat hidup sendiri. Manusia yang satu membutuhkan kehadiran manusia lain untuk saling berinteraksi guna memenuhi segala kebutuhan hidupnya. Interaksi antar manusia di era digital seperti sekarang tidak hanya berkenaan dengan orang yang berdekatan secara fisik. Dengan orang yang jauh bahkan di belahan bumi manapun bisa dilakukan lewat bantuan internet. Oleh karena kebutuhan manusia untuk berinteraksi dengan manusia lain sangatlah penting, maka dibutuhkan suatu keterampilan untuk dapat bersikap yang baik dengan orang lain. Selain untuk bersosialisasi, keterampilan bersikap yang baik juga sangat dibutuhkan guna keberhasilan hidup manusia tersebut. Sikap hidup merupakan faktor penting yang menentukan keberhasilan dalam pergaulan sosial religious (Kusuma, 2017). Penguasaan sikap merupakan pondasi utama akhlak yang mulia. Perbuatan manusia akan sangat ditentukan oleh sikap hidup mereka masingmasing. 
Setiap orang selagi ia masih hidup, selamanya ia akan berperilaku dan melakukan suatu perbuatan. Dengan berbuat berarti seseorang telah melakukan karma. Dari perbuatan karma inilah akan menimbulkan akibat atau phala yang menentukan kehidupan seseorang dimasa sekarang dan masa yang akan datang. Berkarma dalam masa kehidupan sekarang ini berarti mempersiapkan untuk kehidupan yang akan datang. Oleh sebab itu, orang-orang yang sadar akan hal ini, akan berusaha untuk berbuat yang sebaik-baiknya daripada masa-masa terdahulu dan selalu berusaha untuk memperbaiki kualitas diri, sebab setiap orang mengharapkan adanya kehidupan yang lebih baik dan lebih menyenangkan di masa- masa yang akan datang.

Agama Hindu sendiri menyadari hal tersebut serta memberikan solusi atas kebutuhan manusia untuk bergaul dan berinteraksi dengan orang lain. Salah satu ajaran agama Hindu yang memuat tentang perbuatan manusia adalah ajaran Kayika Parisudha sebagai bagian dari Tri Kaya Parisudha. Kayika Parisudha artinya berbuat yang benar atau yang disucikan. Perbuatan seseorang menjadi sangat penting dalam pergaulan karena perbuatan inilah yang secara langsung memberikan efek dan dirasakan oleh orang lain.

Pada hakikatnya melakukan suatu perbuatan adalah sebuah keharusan. Tidak ada seorangpun yang bisa hidup tanpa berbuat sesuatu, karena kata hidup itu sendiri adalah sebuah kata kerja. Bagaimana manusia bisa memberikan makna dalam hidupnya tanpa melakukan suatu perbuatan. Seperti yang termuat di dalam Kitab suci Bhagavadgita III.8 sebagai berikut :

Nityaim kuru karma tvain

Karma jyāyo hy akarmaṇạ

śarìra-yātrāpi ca te

Na prasiddhyed akarmanah

Terjemahan :

Lakukanlah perbuatan-perbuatan seperti yang telah ditetapkan di dalam kitabkitab suci, karena sesungguhnya adalah lebih baik melakukan perbuatan daripada tidak berbuat apa-apa. Bahkan perjalanan badan jasmani inipun tidak akan bisa terjadi tanpa melakukan perbuatan (Darmayasa, 2013).

Menjaga selalu perbuatan kita agar tidak terlepas dari ajaran agama juga merupakan salah satu jalan untuk mencapai kebahagiaan dan tujuan hidup manusia. Manusia harus selalu menyadari bahwa kesempatan untuk lahir sebagai manusia 
sangatlah berharga dan tidak boleh disia-siakan dengan melakukan perbuatan yang bertentangan dengan ajaran agama Hindu. Seperti termuat dalam kitab Sārasamuccaya 9:

Yo durlabhataram prapya manusyam lobhato narah,

Dharmāvamantā kāmātma bhavet sakalavaňcitah

Terjemahan :

Bila ada beroleh kesempatan menjadi orang (manusia), ingkar akan pelaksanaan dharma; sebaliknya amat suka ia mengejar harta dan kepuasan nafsu serta berhati tamak; orang itu disebut kesasar, tersesat dari jalan yang benar (Kadjeng, 1997).

Setiap manusia pada dasarnya ingin menjadi orang yang berguna baik bagi diri sendiri, keluarga maupun masyarakat. Begitu juga generasi muda Hindu yang tidak lain adalah penerus bangsa, agama dan budaya. Konsisten melakukan perbuatan baik sesuai petunjuk dharma, maka tidak diragukan lagi kehidupan orang tersebut akan bermakna. Begitu pula sebaliknya, ketika seseorang mengisi diri dan hariharinya dengan perbuatan-perbuatan yang bertentangan dengan ajaran dharma maka dapat dipastikan kehidupannya dianggap tidak berguna dan tidak berbahagia. Di dalam ajaran agama Hindu hal ini dituangkan dalam kitab Sarasamuccaya 45 sebagai berikut :

Pulakā iva dhānyesu puttikā iva pakșișu Tādrșaste manusyeșu yeșām dharmo na kāranam Terjemahan :

Adapun orang yang sama sekali tidak melakukan laksana dharma, adalah seperti padi yang hampa atau telur busuk, kenyataannya ada, tetapi tidak ada gunanya.

Termuat juga dalam kitab Sarasamuccaya 47 sebagai berikut :

Ye tu dharmmamașūyante buddhimohānvita janāh, Apathā gacchatām teșāmaṇuyātāpi piḍ̂ate:

Terjemahan :

Tambahan pula orang yang ingkar akan perbuatan yang bersandarkan dharma, disebabkan karena angkuhnya, serta tetap ia melakukan perbuatan adharma, juga yang mengikuti tindakannya itu, tak dapat tiada pasti kesedihan yang akan dialaminya (Kadjeng, 1997). 
Oleh karena itu sebagai generasi muda Hindu pada khususnya, selalu menjaga tingkah laku perbuatan haruslah menjadi salah satu prioritas agar hidup menjadi lebih bermakna. Apalagi di era serba digital seperti saat ini dimana tidak ada lagi sekat yang membatasi informasi dan hubungan antara manusia yang satu dengan manusia yang lainnya. Satu saja kekeliruan dalam berperilaku, apabila tersebar melalui internet akan menyisakan jejak digital yang tidak akan bisa dikontrol penyebarannya dan tidak dapat dihapus begitu saja. Oleh karena itu, satu hal yang harus selalu dipegang oleh generasi muda Hindu adalah selalu berpegang teguh pada ajaran dharma agar setiap langkah dan perbuatan tidak menimbulkan penyesalan dan kesedihan dikemudian hari. Dengan didasarkan pada ajaran Kayika Parisudha, generasi muda Hindu dapat menjaga dirinya dari dampak negatif globalisasi dan era digital, agar tidak ikut terbawa arus perkembangan jaman yang semakin tidak terbendung.

\section{IMPLEMENTASI AJARAN TRI KAYA PARISUDHA BAGI GENERASI MUDA HINDU}

Era digital dengan segala akses, kemudahan dan kecepatan yang ditawarkan tidak hanya mengantarkan manusia ke jaman dimana ilmu pengetahuan dan teknologi semakin berkembang, tetapi juga menghantarkan manusia kepada jaman dimana nilainilai kemanusiaan itu sendiri mulai mengalami kemunduran. Menyikapi hal tersebut adanya upaya dalam meminimalisir terjadinya degradasi moral generasi muda Hindu, berbagai macam upaya mutlak diperlukan. Tanpa adanya tindakan-tindakan preventif atau pencegahan, tentu saja masa depan bangsa dan negara sedang dipertaruhkan. Penanaman ajaran-ajaran etika atau susila sangat dibutuhkan oleh generasi muda saat ini untuk membentengi diri dari pengaruh-pengaruh negatif globalisasi. Salah satu ajaran yang perlu ditanamkan dalam diri setiap umat khususnya generasi muda Hindu adalah ajaran Tri Kaya Parisudha itu sendiri.

Implementasi dari ajaran Tri Kaya Parisudha selalu berpayung pada Wiweka, yaitu kemampuan untuk menimbang dan membedakan antara perbuatan yang baik dengan yang kurang baik serta antara perbuatan yang salah dengan perbuatan yang benar. Karena tidak semua perbuatan baik itu benar, dan sebaliknya tidak semua perbuatan yang dirasa kurang baik itu salah. Contohnya bernyanyi dengan suara yang indah dan nyaring adalah baik untuk menghibur, namun jika perbuatan itu perbuatan 
itu dilakukan ketika tetangga sedang sakit parah. Sehubungan dengan hal tersebut maka pikiran, perkataan dan perbuatan seseorang harus benar-benar dikendalikan dan harus bisa menyesuaikan dengan tempat dan situasinya.

Agama Hindu pada dasarnya mengajarkan bahwa segala perkataan dan perbuatan manusia bersumber dari pikiran, hakikatnya sudah menjadi suatu kewajiban bahwa manusia wajib mengendalikan pikirannya. Menjaga kesucian pikiran, perkataan dan perbuatan yang dilakukan juga berdasarkan atas kebenaran atau dharma. Seperti yang termuat di dalam kitab Sarasamuccaya 87:

Bhāvașuddhirmanusyasa vijňeyā sarvakarmasu, Terjemahan:

Anyathā cumbyate kāntā bhāvena duhitānyathā

Dan lain lagi, kehendaknya anda selalu ingat, bahwa kesucian pikiran orang diikuti oleh tindakan atau perbuatannya pada setiap hal nyatanya ; seorang ayah yang mencium istrinya, dan diciumnya pula anaknya, namun berbeda perasaannya sang ayah itu selagi ia mencium kedua orang itu, meskipun sama bersandarkan hati suka (senang) ; jadinya pikiranlah yang merupakan sebab, alasan akan perbedaan (dalam melakukan) perbuatan itu (Kadjeng, 1997).

Pikiran manusia dapat diibaratkan sebagai "monyet" yang selalu gelisah, tidak tenang, selalu melompat kesana dan kemari. Pikiran adalah sekumpulan keinginan. Dalam proses belajar yang baik, sangat penting membuat pikiran terarah dan tenang. Dengan pikiran yang tenang dan terarah, diharapkan perkataan dan perbuatan kita juga akan mengarah pada kebaikan dan kebijaksanaan berdasarkan ajaran agama Hindu (Aryadharma, 2005). Salah satu doa yang dapat digunakan untuk mengarahkan pikiran menuju kebaikan adalah doa yang bersumber dari Yajurveda XXXIV. 3 sebagai berikut:

Yat prajn̄ānam uta ceto dhṛtiśca yajjyotirantar amrtam prajāsu,

Yasmānna 'rte viňcana karma kriyate tanme manah śivasamkalpam astu. Terjemahan:

Yang menjadi sumber pengetahuan utama, dan merupakan kecerdasan serta kekuatan pikiran, yang merupakan api tak kunjung padam pada makhluk hidup; tanpa adanya itu kita tidak mampu berbuat apa-apa, semoga pikiran kami selalu mengarah kepada yang baik (Bose, 2000).

Walapun pikiran itu sendiri sebagai sumber dari segala perkataan dan perbuatan, namun harus disadari bahwa perkataan dan perbuatan itulah yang pada akhirnya bersinggungan secara langsung dengan manusia lainnya. Perkataan dan 
perbuatan manusialah yang akan dinilai dan diberikan makna apakah perkataan dan perbuatannya sesuai atau tidak dengan nilai-nilai sosial dan ajaran agama. Oleh karena itu di dalam ajaran Tri Kaya Parisudha, ketiga aspek tersebut sangatlah diperhatikan, baik itu pikiran, perkataan maupun perbuatan.

Ajaran Tri Kaya Parisudha yang terdiri dari dimensi tiga perilaku yang harus disucikan terimplementasi ke dalam sepuluh macam pengendalian diri yang disebut Karmapatha. Adapun indikator-indikatornya terdiri dari tiga perilaku berdasarkan pikiran yang baik dan benar, empat perilaku berdasarkan atas perkataan yang baik dan benar, dan tiga perilaku berdasarkan atas perbuatan yang baik dan benar. Adapun kesepuluh bagian dari karmaphala tersebut adalah sebagai berikut (1) tidak iri dan dengki pada kepunyaan orang lain, (2) tidak bersikap gemas kepada semua makhluk, (3) percaya tentang kebenaran ajaran karmaphala, (4) tidak berkata jahat, (5) tidak berkata kasar / menghardik, (6) tidak memfitnah, (7) tidak berkata bohong, (8) tidak membunuh, (9) tidak mencuri, dan (10) tidak berzina (Arwati, 2017). Dari kesepuluh macam pengendalian diri tersebut, diharapkan masyarakat khususnya generasi muda Hindu dapat menumbuhkan dan mengembangkan karakter-karakter baik di dalam dirinya untuk mempersiapkan dan mematangkan diri dalam menghadapi era digital.

Sebagai umat Hindu, pastinya mengenal Tri Sandhya sebagai salah satu bentuk pemujaan kepada Ida Sang Hyang Widhi Wasa. Berdasarkan akar katanya Tri Sandhya memiliki arti Tri = tiga dan Sandhya = pergantian waktu. Tri Sandhya dimaknai sebagai persembahyangan yang dilakukan tiga kali sehari disaat terjadinya pergantian waktu dari malam ke pagi, pagi ke siang dan siang ke malam hari. Puja Tri Sandhya itu sendiri adalah sebagai proses penyucian diri agar dapat menghilangkan sifat-sifat negatif yang disebabkan oleh pengaruh nafsu atau keinginan manusia serta meningkatkan sifat-sifat positif dalam diri manusia sehingga tercipta keharmonisan dan keseimbangan baik dengan sesama makhluk hidup maupun alam semesta.

Tri Sandhya sebagai nyanyian pujaan pada dasarnya mengandung komponen-komponen pujian, pengakuan serta permohonan, dan setiap bait di dalam Tri Sandhya ini mengandung maknanya masing-masing. Untuk bait keenam, termuat ajaran mengenai Tri Kaya Parisudha, dimana melalui bait ini umat Hindu memohon pengampunan bagi perbuatan, perkataan serta pikirannya. Hal itu tampak pada penggalan bait ke-6 Tri Sandhya sebagai berikut : 


\section{Om ksàntavyah kàyiko dosah}

ksàntavyo vàciko mama

ksàntavyo mànaso dosah

tat pramàdàt ksamasva màm,

Terjemahan :

Om Sang Hyang Widhi, ampunilah dosa yang dilakukan oleh badan hamba, ampunilah dosa yang keluar melalui kata-kata hamba, ampunilah dosa pikiran hamba, ampunilah hamba dari kelalaian hamba.

Jika ditinjau dengan seksama pada bait keenam tersebut, permohonan ampunan yang pertama tidaklah ditujukan kepada pikiran, melainkan kepada perbuatan dan dilanjutkan dengan permohonan ampun bagi perkataan dan pikiran secara berturut-turut. Hal ini dikarenakan walaupun pikiran adalah sumber dari segala perbuatan dan perkataan, tetapi perbuatan dan perkataanlah yang berdampak secara langsung kepada mahluk lainnya. Menyakiti seseorang secara fisik dan verbal akan langsung terasa jika dibandingkan dengan berpikir untuk menyakitinya. Tetapi pada akhirnya, menyakiti orang lain dengan cara apapun bukanlah hal yang baik dan tidak sesuai dengan ajaran dharma. Berdasarkan bait ke-6 tri sandhya, setiap manusia diharapkan untuk selalu mengintrospeksi diri, baik dari segi perbuatan, perkataan, maupun pikirannya. Tiga aspek dari Tri Kaya Parisudha ini akan sangat menentukan kualitas diri seseorang. Oleh karena itu, setelah melaksanakan Tri Sandhya, perbaikan kualitas diri melalui menjaga perbuatan, perkataan dan pikiran selalu berdasarkan atas dharma harus selalu diusahakan dan diterapkan oleh umat Hindu khususnya generasi muda Hindu di dalam kehidupan sehari-hari agar doanya tersirat juga di dalam perbuatan sehari-harinya.

Ajaran Tri Kaya Parisudha merupakan salah satu ajaran di dalam Etika Hindu atau Susila untuk membangun karakter khususnya karakter generasi muda Hindu dalam menghadapi tantangan di era digital, pada akhirnya mengantarkan umatnya kepada suatu refleksi bahwa sebagai manusia tidak akan pernah bisa terlepas dari hasil dari perbuatan-perbuatannya sendiri (karma phala). Selain menyucikan segala pikiran, perkataan dan perbuatan sebagai bentuk pelaksanaan ajaran agama, implementasi ajaran Tri Kaya Parisudha merupakan cerminan bagi umatnya agar memperlakukan orang sebagaimana orang tersebut ingin diperlakukan. Ketika tidak ingin dibohongi, janganlah pernah berbohong. Jika ingin dihormati, hormatilah orang 
lain terlebih dahulu. Seperti yang termuat di dalam kitab Sarasamuccaya 44 sebagai berikut:

\section{Cruyatām dharmasarvasvam crutvā caivopadhāryatām}

Terjemahan: Atmanah pratikūlāni na paresām samācara

Karena itu perhatikanlah segala perbuatan anda, sehingga anda dapat mengetahui hakikat sejatinya yang disebut dharma; setelah anda mengetahui, simpanlah itu baik-baik di dalam hati; sebagaimana telah hamba katakan dulu, segala yang tidak menyenangkan anda, hal itu jangan hendaknya dilakukan kepada orang lain;

Selain itu, kitab Sarasamuccaya 41 menyebutkan sebagai berikut :

Na tata parasya sandadhyāt pratikulam yadātmanah

Eșa samkșepato dharma kāmādanyat pravartate

Terjemahan :

Maka yang harus anda perhatikan, jika ada hal yang ditimbulkan oleh perbuatan, perkataan dan pikiran, yang tidak menyenangkan dirimu sendiri, malahan menimbulkan duka yang menyebabkan sakit hati; perbuatan itu jangan hendaknya anda lakukan kepada orang lain; jangan tidak mengukur baju di badan sendiri, perilaku anda yang demikian, itulah dharma namanya; penyelewengan ajaran dharma, jangan hendaknya dilakukan (Kadjeng, 1997).

Menjaga perbuatan berdasarkan atas dharma sangatlah perlu dilaksanakan. Berdasarkan sloka di atas, hidup umat khususnya generasi muda Hindu agar menerapkan pola hidup "cermin", dimana meyakini bahwa segala yang dilakukan orang lain kepada diri sendiri adalah refleksi dari bagaimana orang tersebut memperlakukan orang lain. Dengan prinsip hidup tersebut diharapkan untuk selalu mulat sarira atau introspeksi diri dan menjaga tingkah laku kepada orang lain sehingga terwujud kehidupan yang harmonis demi kepentingan bersama.

Melaksanakan Tri Kaya Parisudha dengan sebaik-baiknya, dapat menimbulkan pikiran yang baik. Dari pikiran yang baik akan timbul perkataan yang baik sehingga mewujudkan perbuatan yang baik pula. Dari perbuatan yang baik, maka phala yang diperoleh dari karma yang dilakukan akan baik pula. Berdasarkan uraian di atas, maka dapat disimpulkan bahwa apa yang diperbuat seseorang pasti membawa hasil, entah buruk maupun baik. Bahkan berpikirpun akan membawa hasil. Maka dari itu, setiap manusia harus dapat menguasai pikiran, perkataan dan perbuatannya berdasarkan dharma atau kebenaran. Jangan sebaliknya, pikiran yang bertentangan 
dengan ajaran agama Hindu atau sad ripu yang menguasai hati manusia. Dengan menguasai dan menanamkan pedoman hidup ini dalam lubuk hati maka seseorang akan selalu memperoleh kebahagiaan dan akan menjadi manusia yang bijaksana. Dengan mengimplementasikan ajaran Tri Kaya Parisudha ini dengan sebaik-baiknya, akan membangun karakter generasi muda Hindu sekaligus untuk menghindarkan diri dari dampak negatif era globalisasi.

\section{KESIMPULAN}

Menghadapi era digital seperti saat ini selain membutuhkan kesiapan infrastruktur serta sarana dan prasarana, dibutuhkan juga kesiapan karakter untuk menghadapi berbagai macam perubahan dan tantangan yang menyertai perkembangannya karena era digital ini akan membuka sekat-sekat antara kebudayaan yang memungkinkan berbagai jenis kebudayaan untuk masuk ke tengah-tengah kehidupan masyarakat yang mungkin salah satunya akan sangat bertentangan dengan agama, adat serta budaya ketimuran yang menjadi pondasi dasar dari kehidupan bermasyarakat di Indonesia. Oleh karena itu, dibutuhkan penguatan etika khususnya bagi generasi muda Hindu untuk mencegah dampak-dampak negatif dari era digital. Salah satunya yaitu dengan mengetahui, mempercayai dan mengimplementasikan ajaran Tri Kaya Parisudha.

Tri Kaya Parisudha merupakan bagian dari ajaran Susila dalam Tri Kerangka Dasar agama Hindu, yang terdiri dari 3 (tiga) bagian, yakni berfikir yang baik yang disebut dengan Manacika Parisudha, (2) berkata yang baik yang disebut dengan Wacika Parisudha, dan (3) berprilaku yang baik atau yang disebut dengan Kayika Parisudha. Penerapan ajaran Tri Kaya Parisudha dalam kehidupan sehari-hari sangat relevan untuk membentuk generasi muda Hindu yang baik, serta menjauhkan diri dari hal-hal negatif yang merupakan dampak dari perkembangan era digital seperti saat ini. 


\section{DAFTAR PUSTAKA}

Aryadharma, N. K. S. (2005). Melahirkan Generasi Berkarakter Dewata Kiat Sukses Siswa Menurut Hindu. Denpasar: Pustaka Bali Post.

Bertens, K. (2013). EtikaBertens, K. (2013). Etika. Yogyakarta: PT. Kanisius. Yogyakarta: PT. Kanisius.

Darmayasa. (2013). Bhagavad Gita Nyanyian Tuhan. Denpasar: Yayasan Dharma Sthapanam.

Kadjeng, I. N. (1997). Sarasamuccaya. Surabaya: Paramita.

Pandit, B. (2003). Pemikiran Hindu. Surabaya: Paramita.

Śivānanda, Ś. S. (2005). Pikiran Misteri dan Penaklukannya. Surabaya: Paramita.

Sudharta, T. R. (2003). Slokāntara. Surabaya: Paramita.

Suhardana, K. . (2007). Tri Kaya Parisuda Bahan Kajian untuk Berpikir Baik, Berkata Baik dan Berbuat Baik. Surabaya: Paramita.

Suratmini, N. W. (2012). Dharma Sewanam (Indahnya Melayani Sesama). Surabaya: Paramita.

Yudiantara, I. P. (2016). Sakti Sidhi Ngucap Eksplorasi \& Aplikasi Ilmu Leak Kanda Pat \& Dasa Aksara Untuk Orang Modern. Denpasar: Bali Wisdom.

\section{Jurnal}

Arwati, N. M. (2017). Pendidikan Nilai Etika dalam Teks Lontar Tri Kaya Parisudha Rsi Sesana dan Kitab Suci Sarasamuccaya. Widyacarya, I(1), 94-103.

Hartaka, I. M. (2018). Building Patriotism Through Spiritual Awareness Hindu Religion Perspective. Proceeding International Seminar (ICHECY), 160-164.

Kusuma, I. M. W. (2017). Penerapan Ajaran Trikaya Parisudha Melalui Pendekatan Humanistik. Maha Widya Duta, I(1), 98-106.

Buku terjemahan

Bose, A.C. 1954. Panggilan Veda. Terjemahan oleh I Wayan Maswinara. 2000. Surabaya: Paramita.

Davies, Paul. 1993. Membaca Pikiran Tuhan Dasar-Dasar Ilmiah dalam Dunia yang

Internet

Rasional. Terjemahan oleh Hamzah. 2012. Yogyakarta : Pustaka Pelajar.

Gulo, Yupiter, 2019, Pilihlah "Mindset” Berkembang, Sebab "What You Think, You Become”, (Online), https://www.kompasiana.com, diakses pada tanggal 18 Mei 2019.

Kompas.com. 20 Pebruari, 2019. 2 Poin Utama agar Bertahan di Era Industri 4.0, diakses pada tanggal 19 Mei 2019. 